\title{
The Experiences of Alienation, Insanity and Despair: The Zoo Story and Modernity
}

\author{
Noni Gopal Sutradhar
}

Lecturer, Department of English, Shashidal Alhaj Mohammad Abu Taher College, Cumilla- 3526, Bangladesh Email: nonigopal2212@gmail.com

Received: 07 Nov 2021; Received in revised form: 10 Dec 2021; Accepted: 19 Dec 2021; Available online: 27 Dec 2021 (C)2021 The Author(s). Published by Infogain Publication. This is an open access article under the CC BY license (https://creativecommons.org/licenses/by/4.0/).

\begin{abstract}
The empty materialism of the post-War period brought the people into a particular area of possessing their own grandeur. It gave them the right to wander anywhere they sought after. But it was just like a cage where they were put aside and separated by bars from each other. In the guise of unity it played the role to scatter one from another. They intentionally injected the idea of being superior which consequently mugged the emotions of people and alienated them from each other. The ruling party who became benefitted by the War also became tycoon paying no heed to others. At the same time a sect of young generation lost their faith in the new trends. It made a trouble keeping both the aforesaid sects apart from each other. These two types of people of the post-War society are represented by Peter and Jerry respectively in The Zoo Story. All the necessary sectors i.e. political, social got a crazy look and influenced the contemporary trends in literature. Major collapse in morality increased alarmingly among people. All these matters happened to drive them towards a puzzle. Failing to solve the problems they became frustrated and this shook their mind desperately. The very modern men made them lunatic and thus insanity got its nest in their mind and in their actions. It seems that they are running around the cycle of alienation, insanity and despair keeping the ultimate ruin in its centre. It is not just a story but an up-todate projection of modern life.
\end{abstract}

Keywords-Alienation, Modernism, Despair, theatre of absurd.

\section{CONTEXT}

Albee is inclined to the term, "theatre of absurd," a postWar phenomenon. "Theatre of absurd" attacks the comfortable certainties of religious or political orthodoxy aiming at shocking its audience out of contentment and helping to bring face to face with the harsh facts of the human situation. It projects "the irrationalism, helplessness, and absurdity of life in dramatic forms that reject realistic settings, logical reasoning or a coherently evolving plot" (Abrams 2).

Modernism that came as a consequence of industrialization as well as World War I and II is one of the focal points of The Zoo Story. Modernism turned the daily life outdated in the new economic, social and political conditions of an emerging industrialized world.
"Modernity is a qualitative, not a chronological, category. Just as it cannot be reduced to abstract form, with equal necessity it must turn its back on conventional surface coherence, the appearance of harmony, the order corroborated merely by replication" (Adorno, qtd. in Mundra).

Along with "Modernism" and "Absurdism", Albee focused on "Existentialism" which refers to "the theory that humans are free and responsible for their own actions in a meaningless world" (Hornby 437). Anguish, despair, anxiety, the absurd, authenticity, nothingness are the literary features Albee had in his mind while writing The Zoo Story.

The impacts of "Capitalism" seem to be the vital fact behind Albee's writing in The Zoo Story that brings 
about despair, insanity and alienation. Indeed, capitalist thought came into being as a consequence of modernism and the upheaval of capitalists suppressed the common people.

The waves of the post-War period deliberately broke some of the traditional bases. Creeping tides of modernism shook the root of the old faith and sentiments and brought about a change in both Western art and culture. The catastrophe of the War shook faith in the moral basis, coherence, and durability of Western Civilization. Rise of New York and Chicago as great commercial centers mark the beginning of modern American culture. Everything, "the skyscrapers, the size and variousness of population, the misery of the poor, the bitterness of the battle between labor and capital, the extravagance of the rich, the shattering indifference of urban society towards the individual, was present in New York" (Bradbury 151). "Edward Albee, obviously, is a post-nuclear writer; Apocalypse and eschatology are in the air. His fundamental theme is the collapse of communality, the other as threat. His subject is loss, desolation, spiritual depletion" (Bigsby 125). Observing social amenities and accepting a stereotyped role make it possible for people to converse without communicating to live together while remaining stranger. Albee feels strongly the alienation of the individual in the midst of a group-oriented society.

\section{FOCUS}

"Theatre of Absurd" shows the characters in rebellion against essential beliefs and values of traditional culture and traditional literature. Albee, as one of the followers of absurdist group, represents human life in its faithless search for purpose and meaning. It views human being as an isolated existent and cast into an alien universe. The action is wildly fantastic, yet it is not altogether unfamiliar, for it is not unlike situations most of us have experienced at one time or another in dreams and nightmares.

"Existentialism" is a philosophical movement which emphasizes on individual existence, freedom, and choice. The Existentialists believe that a person should be forced to choose and be responsible without the help of laws, rules, or traditions. Ronald Hayman's remark is also quotable in this context. He has remarked, Jerry's death "like the death of many tragic heroes in earlier plays, is an illustration of the impossibility of living in accordance with the values he represents" (Hayman 151).

A sense of disillusionment, such a collapse of all previously held firm beliefs is a characteristic feature of our own times. The relapse into barbarism, mass murder, and genocide in the course of Hitler's brief rule over Europe during the Second World War and, in the aftermath of that War, spread spiritual emptiness in the outwardly prosperous and affluent societies of Western Europe and the United States (Esslin).

\section{TEXT ANALYSIS}

The Zoo Story is a literary study of how despair, alienation and insanity fall upon the concerned people as a consequence of "Modernism." The characters of the play or most significantly the dialogues uttered by Jerry at the closing part of the play reveal a sharp perception of men's alienation, despair and insanity in a world of spiritual importance. The frustration that comes out of loneliness is the root cause of feeling emptiness inside. Jerry was brought up by his aunt in an unfriendly environment and subsequently his aunt also departed. He lacks love and tries to have least semblance of it from anything he goes by even animals. But each time the happiness of love shows back to him. The following words uttered by Jerry can be stood as a proof of the above mentioned despair in him: "I loved the dog, and I wanted him to love me. I had tried to love, and I had tried to kill, and both had been unsuccessful by themselves" (1.38-39). Jerry lives on the top floor of a four storied building in a laughably small room. But he is alienated from the other inhabitants of the building. The thought "What is gained is loss" (1.40) haunted him throughout his life. And that is what leads him to insanity. When he finds that having everything Peter is not willing to leave the possession of the bench he becomes lunatic that brings about the full stop to his existing unsatisfied life.

Though the play refers to the traumatic portrait of Jerry, the theme of alienation also goes with Peter. Peter and Jerry represent bourgeois society and lost generation respectively. As a representative of bourgeois society Peter never tries to understand Jerry. On the other hand, Jerry cannot go with the changing trends of the new society. Both of them go hand in hand as if they, in T S Eliot's word, "we are trying to communicate without being able to be understood each other." Peter's "grab-anything-mania" is the outcome of "Capitalism." He, as a capitalist, knows no boundary regarding his demand. Capitalism is deeply rooted in his vein. Indicating his capitalistic behavior Jerry remarks that "You have everything, and now you want this bench. Are these the things men fight for?" (1.45) Being a capitalist Peter does not compromise with anything. Though he has everything he denies leaving the bench for Jerry. This harsh reality drives Jerry to death. Jerry appears to be a complete existentialist in this play. His personal choice to possess the bench becomes unique without the necessity of an objective form of truth. He also forces Peter to choose his own decision to give the bench in his 
possession without considering the laws, rules and traditions.

This play presents a disillusioned, harsh, and stark picture of the world. Though often couched in the form of extravagant fantasies, they are never the less essentially realistic, in the sense that they never shirk the realities of the human mind with its despair, fear and loneliness in an alien and hostile universe. The Zoo Story can be viewed as "a sociopolitical critique" indicating a society that values "materialism instead of humanism" (Zinman 171).

\section{COMMENT}

It is a general instinct of modern people that they try to understand the things having viewed their surface not the core. The depth of the things remains undiscovered for being kept untouched. The modern people merely centre their concern on selfishness and self interest being unwilling to sacrifice as clearly seen in Peter's case in The Zoo Story. And what breeds complexity one after another is hurting without realizing the heart. Even our society gives, more who has more, less who possesses less, and Jerry is a conspicuous example of this in this play. Such an effect of modernity turned the whole world into a "zoo" where people are caged in nice buildings and are separated by bars of psychological, social, economic, and many to name, paradigms. The modern people want to grasp everything whether it is necessary or unnecessary to them. They like to have all the things under their own grip to dominate over others. They can neither endure sorrows of separation nor enjoy the pleasure of union which is respectively represented by Jerry and Peter.

\section{REFERENCES}

[1] Abrams, M H. A Glossary of literary Terms. $7^{\text {th }}$ ed. India: 2000.

[2] Albee, Edward. The Zoo Story. England: Penguin, 1965.

[3] Bigsby, C W E. "Edward Albee: journey to apocalypse." Modern American Drama,1948- 2000. UK: 2000.

[4] Esslin, Martin. Introduction. The Zoo Story. By Edward Albee. England: Penguin, 1965. 8-19

[5] Homberger, Eric. "Chicago and New York: Two Versions of American Modernism." Modernism: A Guide to European Literature, 1890-1930. Ed. Bradbury, Malcolm, and James McFarlane. England: Penguin, 1991.

[6] Heidegger, $\quad$ M. $\quad 9.0 \quad$ May 2010. <http://www.thecry.com/existentialism>

[7] Hornby, A S. Oxford Advanced Learner's Dictionary. Ed. Wehmeier, Sally, and Michael Ashby. $6^{\text {th }}$ ed. New York: Oxford University Press, 2000.

[8] Mundra, S. C. The Zoo Story: A Critical Study. $2^{\text {nd }}$ ed. Bareilly: Prakash, 1994.

[9] Zinman. 3.0 May 2010. <http://muse.jhu.edu> 